\title{
PENERAPAN PENDEKATAN PEMECAHAN MASALAH TERBUKA (OPEN ENDED) DALAM MENINGKATKAN HASIL BELAJAR MATEMATIKA SISWA
}

\author{
I Nyoman Trigunawan \\ SMP Negeri 1 Negara \\ Email: inyomantrigunawan@yahoo.com
}

\begin{abstract}
ABSTRAK
Pendekatan Pemecahan masalah didefinisikan sebagai prosedur yang digunakan sebagai usaha mencari jalan keluar dari suatu kesulitan serta merupakan suatu aktivitas intelektual dengan menggunakan segala pengetahuan, ketrampilan, dan penalaran yang dimilkinya. Pemecahan masalah terbuka (openended problem solving) melibatkan masalah-masalah yang memiliki cara penyelesaian lebih dari satu, untuk memperoleh satu jawaban yang benar. Tujuan dari penelitian ini adalah untuk mengetahui penerapan pendekatan pemecahan masalah terbuka (open ended) dalam meningkatkan hasil belajar matematika siswa. Penelitian ini termasuk jenis penelitian tindakan kelas (PTK) dengan rancangan siklustis. Dalam penelitian ini digunakan subjek penelitian sebanyak 24 siswa, yang diambil dari siswa kelas VIIK yang tidak memenuhi kriteria ketuntasan minimal (KKM). Objek penelitian yang disasar adalah hasil belajar matematika siswa. Setelah data terkumpul, kemudian dianalisis dengan analisis deskriptif kuantitatif. Hasil analisis data menunjukkan peningkatan rerata hasil belajar matematika dari prasiklus ke siklus I sebesar 5,39 poin, prasiklus ke siklus II sebesar 17,56 poin, dan siklus I ke siklus II sebesar 12,17 poin. Berpijak atas hasil analisis data ini, dapat disimpulkan bahwa penerapan pendekatan pemecahan masalah terbuka (open ended) dapat meningkatkan hasil belajar matematika siswa.
\end{abstract}

Kata kunci: Pemecahan masalah terbuka (open ended), dan hasil belajar

\begin{abstract}
Problem solving approach is defined as a procedure that is used as an effort to find a way out of difficulties and is an intellectual activity using all the knowledge, skills, and reasoning it has. Open problem solving involves problems that have more than one way of solving, to get one correct answer. The purpose of this study is to investigate the application of open problem solving approaches in improving student mathematics learning outcomes. This research is a type of classroom action research (CAR) with a design cycle. In this study, 24 research subjects were used, taken from VIIK grade students who did not meet the minimum completeness criteria (KKM). The object of the targeted research is student learning outcomes in mathematics. After the data is collected, it is then analyzed by quantitative descriptive analysis. The results of data analysis showed an average increase in mathematics learning outcomes from pre-cycle to cycle I by 5.39 points, pre-cycle to cycle II by 17.56 points, and cycle I to cycle II by 12.17 points. Based on the results of this data analysis, it can be concluded that the application of an open problem solving approach can improve student mathematics learning outcomes
\end{abstract}

Keywords: open ended problem solving and learning outcomes 


\section{PENDAHULUAN}

Pendidikan adalah suatu usaha yang terencana untuk membantu perkembangan potensi dan kemampuan subyek didik sehingga bermanfaat bagi dirinya sendiri dan masyarakat. Terkait dengan hal itu keberhasilan kegiatan belajar mengajar sangat tergantung pada kwalitas pembelajaran dimana kriteria kualitas pembelajaran dapat dilakukan melalui keberhasilan dalam penilaian terhadap kemampuan berfikir siswa. Menurut Nurman, Salah satu prinsip penilaian pada kurikulum berbasis kompetensi adalah menggunakan acuan kriteria, yakni menggunakan kriteria tertentu dalam menentukan kelulusan peserta didik. Kriteria paling rendah untuk menyatakan peserta didik mencapai ketuntasan dinamakan Kriteria Ketuntasan Minimal (KKM) (Nurman, 2012). Setiap mata pelajaran pada suatu SMP pasti mempunyai kriteria ketuntasan minimal (KKM) untuk bisa dikatakan mencapai ketuntasan belajar (mastery learning).

KKM harus ditetapkan sebelum awal tahun ajaran dimulai. Seberapapun besarnya jumlah peserta didik yang melampaui batas ketuntasan minimal, tidak mengubah keputusan pendidik dalam menyatakan lulus dan tidak lulus pembelajaran. Acuan kriteria tidak diubah secara serta merta karena hasil empirik penilaian. Pada acuan norma, kurva normal sering digunakan untuk menentukan ketuntasan belajar peserta didik jika diperoleh hasil rata-rata kurang memuaskan. Nilai akhir sering dikonversi dari kurva normal untuk mendapatkan sejumlah peserta didik yang melebihi nilai 6,0 sesuai proporsi kurva. Acuan kriteria mengharuskan pendidik untuk melakukan tindakan yang tepat terhadap hasil penilaian, yaitu memberikan layanan remedial bagi yang belum tuntas dan atau layanan pengayaan bagi yang sudah melampaui kriteria ketuntasan minimal.

KKM untuk mata pelajaran matematika di SMP Negeri 1 Negara pada semester gasal tahun pelajaran 2018/2019 adalah 75. Pada semester gasal di kelas VIIK setelah dilakukan pengukuran dalam pokok bahasan bilangan pecahan diperoleh hasil sebagai berikut. Sebanyak 7 siswa memenuhi KKM dan 24 siswa berada di bawah KKM. Dari hasil pengukuran pokok bahasan ini, dapat diketahuii bahwa proses pembelajaran yang dilakukan oleh guru matematika di kelas tersebut kurang optimal. Menurut (Artini, 2011), kurang optimalnya proses pembelajaran yang dilaksanakan bisa bersumber pada metode pembelajaran, tidak menggunakan media dalam pembelajaran, alat evaluasi yang tidak memilikii blueprint, tidak tersedia buku matematika yang memenuhi tuntutan kurikulum, paradigma guru yang menganut sistem transfer pengetahuan, tidak menganut filosofi konstruktivisme, dan guru yang sering meninggalkan kelas.

Dalam pengajaran yang menggunakan metode ceramah, membuat siswa jenuh mendengar ceramah guru karena variasi mengajar guru tidak ada sehingga siswa cendrung untuk mengantuk dan tidak bisa untuk berfikir menyebabkan siswa menjadi diam karena interaksi yang terjadi hanya satu arah yaitu dari guru kesiswa saja atau perhatian terpusat pada guru sedangkan para siswa hanya menerima secara pasif, mirip anak balita yang sedang disuapi. Dalam hal ini, timbul kesan siswa hanya sebagai objek yang selalu 
menganggap benar apa-apa yang disampaikan guru. Padahal, posisi siswa selain sebagai penerima pelajaran, ia juga menjadi subjek pengajaran dalam arti individu yang berhak untuk aktif mencari dan memperoleh sendiri pengetahuan dan keterampilan yang dibutuhkan.

Asumsi tersembunyi guru di sekolah menengah yang menyatakan pengetahuan dapat dipindahkan secara utuh dari pikiran guru ke pikiran siswa yang dituangkan dalam bentuk metode pembelajaran konvensional dapat menimbulkan miskonsepsi pada diri siswa. Efek lanjut dari miskonsepsi yang dialami siswa adalah rendahnya hasil belajar siswa dalam bidang studi matematika misalnya. Untuk itu, perlu dilakukan perbaikan di dalam menyampaikan materi ajar bagi para guru di sekolah menengah.

Menurut (Puger, 2004), untuk meningkatkan hasil belajar siswa diperlukan strategi atau pendekatan maupun metode pembelajaran yang dapat mengembangkan penanaman konsep, pemahaman serta penalaran, dan memotivasi kegiatan belajar siswa. Sehaluan dengan hal itu maka salah satu pendekatan pembelajaran yang dapat menumbuhkan pemahaman, penalaran, dan memotivasi kegiatan belajar siswa adalah dengan menggunakan pemecahan masalah. Pendekatan Pemecahan masalah didefinisikan sebagai prosedur yang digunakan sebagai usaha mencari jalan keluar dari suatu kesulitan. Ini berartii pemecahan masalah merupakan suatu aktivitas intelektual yang tinggi dengan menggunakan segala pengetahuan, ketrampilan, dan penalaran yang dimilkinya. Pemecahan masalah terbuka (open-ended problem solving ) melibatkan masalah- masalah yang memilki cara penyelesaian lebih dari satu, untuk memperoleh jawaban yang sama atau satu jawaban yang benar (Sawada, 1997) Pemecahan masalah terbuka, memfokuskan pada penerapan pembelajaran yang dirancang dengan struktur pembelajaran yaitu : (1) mulai dengan masalah riil yang biasa ditemukan oleh siswa, (2) masalah berhubungan dengan dunia siswa, (3) masalah sesuai dengan materi yang akan dipelajari oleh siswa, (4) memberikan siswa tanggung jawab utama untuk membentuk dan mengarahkan pembelajarannya sendiri, (5) menggunakan kelompok-kelompok kecil dalam pembelajaran, dan (6) menuntut siswa untuk menampilkan apa yang telah mereka pelajari. Berpijak atas kenyataan-kenyataan di atas, dapat dirumuskan masalah sebagai berikut. Apakah penerapan pendekatan pemecahan masalah terbuka dapat meningkatkan hasil belajar matematika siswa kelas VIIK SMP Negeri 1 Negara?

Untuk mencapai hasil belajar siswa yang memenuhi KKM, guru-guru di sekolah menengah dapat menempuh atau dengan menggunakan beragam cara. Mulai dari memperbaiki kualitas persiapan pembelajaran, proses pembelajaran, dan asesmen yang dilaksanakan. Terkait dengan hal ini, Sudiarta menyatakan beberapa faktor yang dapat diidentifikasi sebagai penyebab rendahnya hasil belajar matematika siswa SMP adalah pendekatan guru dalam mengajar selalu berorientasi pada soal metode mengajar yang diterapkan bersifat konvensional, kurang mengadopsi model belajar konstruktivis, guru tidak memakai literatur yang relevan dan berlaku secara umum, tidak melakukan pengkonkretan konsep sebelum proses pembelajaran 
dimulai, media atau sarana pembelajaran yang kurang memenuhi standar, dan siswa kurang dilatih berpikir kritis menurut aturanaturan logika (Sudiarta, 2010)

Sehaluan dengan pendapat Sudiarta di atas, (Fathoni, 2014), untuk meningkatkan proses pembelajaran diperlukan suatu metode. Penggunaan metode pembelajaran secara tepat oleh guru akan dapat menciptakan suasana pembelajaran yang penuh tangungjawab, siswa aktif bertanya maupun mengemukakan pendapat, sehingga siswa akan mampu secara optimal untuk aktif mengikuti proses pembelajaran. Salah satu metode pembelajaran yang dapat menumbuhkan pemahaman, penalaran, dan memotivasi kegiatan belajar siswa adalah dengan menggunakan metode pemecahan masalah (problem solving). Sehingga pengungkapan konsep-konsep dalam suatu bidang studi dapat diwujudkan melalui caracara yang rasional, komonikatif, edukatif, dan kekeluargaan. Ketidakmampuan siswa dalam memahami konsep-konsep matematika dengan benar. Konsep-konsep dalam ilmu matematika secara garis besar dapat dibagi dalam dua kategori, yaitu konsep konkret dan konsep terdefinisi. Konsep konkret digeneralisasi dalam pengamatan langsung atau kontekstual, konsep terdefinisi adalah konsep yang ditetapkan oleh para pakar dan digunakan untuk menjelaskan suatu objek seperti konsep tentang akseoma atau dalil.

Sehubungan dengan penggunaan metode pembelajaran, seorang guru harus jeli (prigel) di dalam memilih metode pembelajaran yang akan diterapkan di kelas. Walaupun dalam dunia pendidikan terdapat banyak metode pembelajaran, namun tidak semua metode ampuh untuk mencapai tujuan pembelajaran pada setiap pokok bahasan. Suatu metode pembelajaran hanya ampuh untuk suatu pokok bahasan tertentu, namun di lain pihak kurang ampuh untuk mencapai tujuan pembelajaran pada pokok bahasan yang lainnya. Hal ini sesuai dengan pernyataan yang dikemukakan oleh (Soetomo, 1993) bahwasannya metode yang tepat untuk salah satu tujuan pembelajaran atau bahan pembelajaran belum tentu tepat untuk tujuan dan bahan pembelajaran yang berbeda. Sehingga pemilihan metode mengajar merupakan spesifik pada proses pembelajaran tertentu. Rendahnya UN matematika pada kebanyakan SMP di Bali, jika dikaji dari metode pembelajaran yang diterapkan oleh guru-guru matematika pada hakikatnya disebabkan oleh guru-guru matematika tersebut menganggap remeh peran metode pembelajaran di dalam memunculkan hasil belajar siswa dan adanya suatu asumsi tersembunyi, yaitu pengetahuan dapat dipindahkan secara utuh dari pikiran guru ke pikiran siswa. Dengan dua anomali persepsi guru tersebut, para guru memfokuskan diri pada upaya penuangan pengetahuan ke dalam kepala siswanya. Dalam hal ini mungkin saja guru telah merasa mengajar dengan baik, namun para siswanya tidak belajar, dalam arti bahwa tidak terjadi perubahan struktur kognitif pada diri pebelajar. Sudiarta berpendapat bahwa asumsi tersebut sudah saatnya untuk ditinggalkan, terutama dalam pembelajaran matematika, mengingat materi pelajaran matematika sebagian besar merupakan pengetahuan logika-matematika (logico-mathematical knowledge) yang tidak dapat dipindahkan secara utuh dari pikiran guru ke pikiran siswa. 
Dengan asumsi yang keliru tersebut, para guru memfokuskan diri pada upaya penuangan pengetahuan sebanyak mungkin kepada siswa dengan target menghabiskan materi yang dituntut di dalam kurikulum. Atas dasar asumsi ini, metode transfer informasi akan dianggap sebagai metode yang paling efektif dalam menuangkan pengetahuan kepada siswa. Model pembelajaran matematika seperti ini akan menimbulkan kebosanan bagi siswa, akhirnya pembelajaran matematika menjadi tidak menarik, tidak disenangi siswa, dan pada akhirnya pelajaran matematika terasa sangat sulit. Sebagai konsekuensinya, hasil belajar yang dicapai siswa belum sesuai dengan harapan seperti yang tercermin dari UN matematika siswa hampir disemua sekolah menengah yang boleh dibilang cukup memprihatinkan.

Model belajar yang diterapkan oleh kebanyakan guru matematika di SMP perlu segera diluruskan, karena asumsi transfer pengetahuan dari pikiran guru ke pikiran siswa tidak sesuai dengan model belajar konstruktivisme. Belajar menurut teori konstruktivisme merupakan kegiatan yang aktif dilakukan oleh pebelajar itu sendiri untuk membangun pengetahuannya di dalam struktur kognitifnya. Sehubungan dengan hal ini, (Piaget, 1970) menyatakan To know an object is act upon it and transform it .... To know, threfore, is to assimilate reality into the structure of transformation, and these are the structures that intellegence constructs as a direct reflection of our actions. Pernyataan ini secara ringkas dapat diartikan bahwa untuk mengetahui suatu objek kita harus melakukan aksi terhadap objek tersebut dan mentransformasinya. Tahu berarti mengasimilasi realita ke dalam struktur-struktur transformasinya. Menjadi tahu adalah suatu proses aktif dalam mana individu berinteraksi dengan lingkungan dan mentransformasinya di dalam pikiran dengan menggunakan struktur-struktur yang telah ada dalam pikiran. Struktur pikiran merupakan sumber dari pemahaman manusia terhadap dunia realita. Jika disimak lebih dalam, akan terlihat bahwa pendapat Piaget seperti yang dikemukakan di atas beroposisi dengan: 1) teori yang memandang pikiran sebagai suatu "tabula rasa" yang menyerap informasi tanpa melalui strukturisasi, 2) teori yang menyatakan bahwa struktur-struktur mental telah ada sejak lahir, dan 3) teori realisme yang memandang bahwa pengetahuan merupakan tiruan atau replikan realita di dalam pikiran kita. Piaget mengemukakan bahwa struktur mental atau skemata-skemata interpretasi berkembang sebagai hasil interaksi yang lebih kompleks dengan dunia realitas secara berurut. Karena hasil karyanya inilah, maka Piaget diberi julukan sebagai konstruktivis yang pertama.

Metode transfer pengetahuan yang dilakukan oleh seorang guru di dalam proses pembelajarannya dicetuskan dalam bentuk metode ceramah. Metode ceramah atau lazim juga dikenal sebagai metode konvensional merupakan metode mengajar dengan menyampaikan informasi dan pengetahuan secara lisan kepada sejumlah siswa yang pada umumnya mengikuti secara pasif. Dalam hal ini biasanya guru memberikan uraian mengenai topik tertentu di tempat tertentu dan dengan alokasi waktu tertentu pula (Fathurrohman, 2007)

\section{METODE PENELITIAN}


Penelitian ini merupakan penelitian tindakan kelas (PTK). (Sudarsono, 1999) menyatakan PTK merupakan suatu bentuk penelitian yang dilaksanakan oleh guru untuk memecahkan masalah yang dihadapi dalam melaksanakan tugas pokoknya, yaitu mengelola pelaksanaan kegiatan pembelajaran dalam arti luas. Tujuan PTK secara umum adalah untuk memperbaiki pelaksanaan pembelajaran.

Penelitian tindakan kelas ini menggunakan rancangan siklustis yang diadopsi dari model (Kemmis, 1988). Setiap siklus terdiri atas empat tahapan, yakni tahap perencanaan, pelaksanaan, observasi dan refleksi. Data dalam penelitian ini dapat dikaji pada tahap observasi pada masingmasing siklus, sedangkan indikator keberhasilan pelaksanaan tindakan dapat dikaji pada tahap refleksi setiap siklus. Indikator keberhasilan pelaksanaan tindakan adalah sebanyak $80 \%$ dari subjek penelitian pada kelas VIIK memperoleh skor yang memenuhi KKM. Jika indikator keberhasilan sudah dipenuhi, berarti kegiatan penelitian dihentikan pada siklus yang bersangkutan.

Subjek penelitian pada penelitian tindakan kelas ini adalah semua siswa kelas VIIK yang tidak memenuhi KKM. Jumlah siswa yang tidak memenuhi KKM pada kelas yang bersangkutan sebanyak 24 siswa. Subjek penelitian setelah mengikuti tindakan yang sudah direncanakan oleh guru matematika kemudian diukur hasil belajar matematikanya. Dengan demikian, objek penelitian ini menyasar tentang hasil belajar matematika siswa.

Instrumen penelitian yang digunakan untuk mengumpulkan data berupa tes hasil belajar matematika. Pra-siklus menggunakan tes hasil belajar matematika pada pokok bahasan membandingkan pecahan, yang terdiri atas 10 butir. Siklus I menggunakan tes hasil belajar matematika pada pokok bahasan penjumlahan dan pengurangan pecahan, yang terdiri atas 10 butir. Siklus II menggunakan tes hasil belajar matematika pada pokok bahasan perkalian dan pembagian pecahan, yang terdiri atas 10 butir. Butir tes hasil belajar matematika sudah diturunkan dari indikator yang bersesuaian.

Setelah data terkumpul, yakni pada tahap observasi kedua siklus penerapan tindakan, selanjutnya dianalisis dengan analisis deskriptif kuantitatif. Analisis deskriptif kuantitatif merupakan proses analisis data dengan membandingkan rerata skor hasil belajar matematika pada prasiklus dengan siklus I, prasiklus dengan siklus II, dan siklus I dengan siklus II. Dari gambaran peningkatan skor rerata yang diperoleh dapat ditarik suatu inferensi.

\section{HASIL DAN PEMBAHASAN Hasil Penelitian}

Pada prasiklus digunakan metode pembelajaran konvensional untuk menyajikan materi ajar membandingkan bilangan pecahan. Setelah dilakukan pengukuran ternyata diperoleh hasil sebagai berikut. Sebanyak 7(22,6\%) siswa memperoleh skor memenuhi KKM dan 24 $(77,4 \%)$ siswa memperoleh skor dii bawah KKM, dengan rerata hasil belajar matematika sebesar 61,94 .

Pada siklus I digunakan pendekatan pemecahan masalah terbuka (open ended) untuk mengomunikasikan materi ajar penjumlahan dan pengurangan pecahan. Hasill pengukuran menyatakan sebanyak 11 
$(45,83 \%)$ siswa memperoleh skor memenuhi KKM dan 13 (54,17\%) siswa memperoleh skor tidak memenuhi KKM, dengan rerata hasil belajar matematika sebesar 67,33. Oleh karena indikator keberhasilan belum terpenuhi, maka penelitian tindakan kelas ini dilanjutkan pada siklus II.

Pada siklus II digunakan pendekatan pemecahan masalah terbuka (open ended) untuk mengomunikasikan materi ajar perkalian dan pembagian pecahan. Hasil pengukuran menyatakan sebanyak 22 (91,67\%) siswa memperoleh skor memenuhi KKM dan sebanyak 2 (8,33\%) siswa memperoleh skor tidak memenuhi KKM, dengan rerata hasil belajar matematika sebesar 79,50. Oleh karena indikator keberhasilan sudah terpenuhi, maka penelitian tindakan kelas ini tidak dilanjutkan pada siklus berikutnya.

Hipotesis tindakan yang diuji kebenarannya berbunyi "penerapan pendekatan pemecahan masalah terbuka (open ended) dapat meningkatkan hasil belajar matematika siswa". Hipotesis tindakan ini selanjutnya diuji melalui analisis data dengan analisis deskriptif kuantitatif.

Perbandingan rerata hasil belajar matematika siswa dari prasiklus ke siklus I menunjukkan peningkatan skor sebesar 5,39 ( 61,94 - 67,33) poin, prasiklus ke siklus II menunjukkan peningkatan skor sebesar 17,56 (61,94 - 79,50) poin, dan siklus I ke siklus II menunjukkan peningkatan skor sebesar 12,17 (67,33 - 79,50) poin. Dari ketiga perbandingan rerata skor hasil belajar matematika yang dilakukan ternyata ketiga perbandingan tersebut menunjukkan peningkatan, yakni sebesar 5,39 poin, 17,56 poin, dan 12,17 poin. Oleh karena ketiga perbandingan rerata skor hasil belajar matematika menunjukkan peningkatan, maka hipotesis tindakan yang diajukan ternyata benar.

\section{Pembahasan}

Temuan dalam penelitian ini menyatakan penerapan pendekatan pemecahan masalah terbuka (open ended) dapat meningkatkan hasil belajar matematika siswa. Hal ini disebabkan oleh terjadi perubahan paradigma pembelajaran, yakni dari pengetahuan bisa dipindahkan secara utuh dari pikiran guru ke pikiran siswa menuju pada pengetahuan dapat dikonstruksi oleh siswa itu sendiri. Melaksanakan penelitian kemampuan penalaran dan komunikasi matematika siswa yang diajarkan dengan pendekatan pemecahan masalah terbuka (open-ended) lebih baik dari pada kemampuan penalaran dan komunikasi matematika siswa yang diajarkan secara konvensional. Demikian juga (Wulandari, 2007) melaksanakan penelitian dengan menerapkan model pembelajaran dengan strategi pemecahan masalah terbuka (open-ended) dapat meningkatkan pemahaman konsep matematika siswa

Lebih lanjut (Fathurrohman, 2007) menyatakan metode pembelajaran konvensional merupakan metode pembelajaran yang disampaikan secara lisan oleh guru bidang studi kepada sejumlah siswa yang pada umumnya mengikuti secara pasif. Berbeda dengan pembelajaran melalui pendekatan pemecahan masalah terbuka (open-ended) merupakan pembelajaran matematika untuk membantu siswa mengembangkan sikap kreatif dan pola pikir matematis siswa yang 
dikembangkan semaksimal mungkin sesuai dengan kemampuan setiap siswa sehingga siswa mempunyai kesempatan untuk berfikir dengan bebas sesuai dengan minat dan kemampuannya. Bahkan (Sudiarta, 2010) menyatakan agar hasil belajar matematika siswa meningkat diharapkan guru-guru matematika di sekolah menengah untuk menghindari menggunakan metode pembelajaran konvensional, atau beralih ke metode pembelajaran konstruktivis. Metode pembelajaran konstruktivis merupakan metode pembelajaran yang menuntut siswa untuk mengonstruksi pengetahuan secara mandiri dalam struktur kognitifnya. Metode pembelajaran konstruktivis menuntut aktivitas siswa di dalam mengikuti proses pembelajaran di kelas, atau lebih dikenal dengan sebutan student-centered. Metode pembelajaran pemecahan masalah merupakan salah satu yang termasuk dalam ranah metode pembelajaran konstruktivis.

Metode pembelajaran yang beraliran teacher-centered sebetulnya lebih banyak menimbulkan miskonsepsi pada siswa. Hal ini disebabkan oleh hanya guru yang aktif dalam proses pembelajaran, sedangkan siswa hanya menonton aktivitas guru di dalam melaksanakan proses pembelajaran. Guru yang beraliran teacher-centered lupa bahwa dalam proses pembelajaran tersebut yang aktif mengonstruksi pengetahuan adalah siswa. Berbeda dengan aliran teacher-centered, bila terjadi miskonsepsi di antara siswa yang menganut aliran studentcentered, maka siswa yang bersangkutan bisa berdiskusi dengan siswa lainnya yang sudah memahami konsep yang bersangkutan. Seorang guru harus bisa menghindarkan siswanya mengalami miskonsepsi. Makin kecil siswa yang mengalami miskonsepsi berarti makin tinggi hasil belajar siswa. Makin tinggi hasil belajar siswa berarti makin tinggi keberhasilan proses pembelajaran seorang guru di kelas yang bersangkutan.

\section{SIMPULAN DAN SARAN}

Analisis data dalam penelitian ini menyatakan hasil belajar matematika siswa dari prasiklus ke siklus I meningkat 5,39 poin, prasiklus ke siklus II meningkat 17,56 poin, dan siklus I ke siklus II meningkat 12,17 poin. Dengan kata lain, penerapan pendekatan pemecahan masalah terbuka (open ended) dapat meningkatkan hasil belajar matematika siswa.

Berpijak atas simpulan yang sudah dikemukakan, dapat diajukan saran sebagai berikut. 1) Bagi peneliti yang ingin membuktikan keampuhan dari penerapan pendekatan pemecahan masalah terbuka (open ended) diharapkan menggunakan materi ajar yang lain pada sekolah di mana peneliti berafiliasi. 2) Bagi guru-guru matematika yang ingin melanjutkan penelitian ini, diharapkan untuk memilih objek penelitian yang lainnya, misalnya motivasi belajar siswa. 3) Bagi guru-guru matematika yang menemukan masalah pembelajaran yang sama, dapat mengadopsi hasil penelitian ini dengan menggunakan variasi alat peraga pada penerapan pendekatan pemecahan masalah terbuka (open ended).

\section{DAFTAR PUSTAKA}

Artini, K. (2011). Faktor-Faktor yang Mempengaruhi Hasil Belajar Siswa.

Fathoni, I. M. (2014). Peningkatan dan keaktifan hasil belajar melalui metode 
prileksi pada siswa kelas V SDN II

Pracimantoro Kabupaten Wonogiri

tahun 2013/2014. Universitas

Muhammadyah Surakarta.

Fathurrohman, P. dan M. S. S. (2007).

Strategi Belajar Mengajar Melalui

Pemahaman Konsep Umum \& Konsep

Islami.

Kemmis, S.: R. M. (1988). The Action

Research Planner.

Nurman. (2012). Pengertian dan Fungsi Kriteria Ketuntasan Minimal (KKM).

Piaget, J. (1970). Genetic Epistemology.

Puger, I. G. N. (2004). Mengaplikasikan Metode Pembelajaran Kooperatif.

Sawada. (1997). What is the open-ended Problem Solving?

Soetomo. (1993). Dasar - Dasar Interaksi Belajar Mengajar.

Sudarsono. (1999). Pedoman Pelaksanaan Penelitian Tindakan Kelas (PTK.

Jurnal Yogyakarta.

Sudiarta, W. (2010). Pengaruh Penyisipan Berpikir Silogisme dalam Proses Pembelajaran Terhadap Prestasi Belajar IPA pada Siswa SMP Negeri 1 Denpasar.

Wulandari, Y. (2007). Model Pembelajaran berbasis komunikasi dengan strategi pemecahan masalah open-ended pada siswa kelas VIII C2 SMP Negeri 1 Singaraja. Undiksha Singaraja. 